\title{
Toxoplasma gondii: diagnosis of experimental and natural infection in pigeons (Columba livia) by serological, biological and molecular techniques
}

\author{
Toxoplasma gondii: diagnóstico da infecção experimental e natural em pombos (Columba livia)
} por métodos sorológicos, biológicos e moleculares

Fernanda Sartori Lima de Godoi ${ }^{1}$; Sandra Mayumi Nishi ${ }^{1}$; Hilda Fátima de Jesus Pena ${ }^{1}$; Solange Maria Gennari ${ }^{1 *}$

${ }^{1}$ Departamento de Medicina Veterinária Preventiva e Saúde Animal, Faculdade de Medicina Veterinária e Zootecnia, Universidade de São Paulo - USP

Received July 26, 2010

Accepted September 24, 2010

\begin{abstract}
This study aimed to diagnose experimental and natural Toxoplasma gondii infection in pigeons (Columba livia) by serological, biological and molecular techniques. Twelve pigeons, free of infection, were inoculated with 50 sporulated oocysts of $T$. gondii (VEG sample) and four remained uninfected controls. Four birds (three infected and one control) were euthanized at 15,30, 45 and 60 days post-infection (dpi), and their tissues were used to perform a bioassay in mice and nested-PCR using B1 gene as target. Blood was obtained weekly and it was tested for the presence of anti-T. gondii antibodies by the indirect fluorescent antibody test (IFAT) and modified agglutination test (MAT). Seven (58.3\%) out of 12 inoculated pigeons were positive by serological techniques and titers ranged between 1:40 and 1:5120 by MAT and between 1:512 and 1:4096 by IFAT. Complete agreement was seen between the results obtained by serological techniques and nested-PCR in seven positive birds. In the bioassay in mice, five (41.7\%) out of 12 pigeons inoculated were positive to $T$. gondii. Only one pigeon died at 23 dpi due to toxoplasmosis. A second study with free-living pigeons was performed for detection of anti-T. gondii antibodies. Birds were captured in the municipalities of São Paulo, Ibiúna and Sorocaba, São Paulo State, Southeastern Brazil. All 126 free-living birds were negative to anti-T. gondii antibodies by MAT (titer < 1:5). Bioassays were performed in mice with tissues from all captured birds and T. gondii was not isolated in any pigeon.
\end{abstract}

Keywords: Toxoplasma gondii, pigeons, experimental infection, bioassay, nested-PCR.

\section{Resumo}

O presente estudo teve por objetivo diagnosticar a infecção experimental e natural pelo Toxoplasma gondii em pombos (Columba livia) por técnicas sorológicas, biológicas e moleculares. Doze pombos, livres de infecção, foram inoculados com 50 oocistos esporulados de T. gondii (amostra VEG), e quatro permaneceram como controles não infectados. Aos 15, 30, 45 e 60 dias pós-infecção (dpi), quatro aves (três infectadas e uma controle) foram sacrificadas e com seus tecidos realizou-se bioensaio em camundongos e nested-PCR, utilizando-se B1 como gene alvo. Sangue, para a pesquisa de anticorpos anti-T. gondii, foi obtido semanalmente, e a presença de anticorpos foi determinada pela reação de imunofluorescência indireta (RIFI) e pela técnica de aglutinação modificada (MAT). Dos 12 pombos inoculados, sete $(58,3 \%)$ foram positivos pelas técnicas sorológicas, apresentando títulos que variaram de 40 a 5.120 no MAT e de 512 a 4.096 na RIFI. Concordância total foi observada entre os resultados obtidos pelas técnicas sorológicas e pela nested-PCR com sete animais positivos. No bioensaio em camundongos, dos 12 pombos inoculados, cinco (41,7\%) foram positivos ao T. gondii. Apenas um pombo veio a óbito no $23^{\circ} \mathrm{dpi}$, devido à toxoplasmose. Um segundo estudo, com pombos de vida livre, foi realizado para a pesquisa de anticorpos anti-T. gondii. As aves foram capturadas nos municípios de São Paulo, Ibiúna e Sorocaba, Estado de Sáo Paulo. Todos os 126 pombos de vida livre foram negativos a anticorpos anti-T. gondii, testados pelo MAT (título < 5). Foram realizados bioensaios em camundongos com tecidos de todas as aves capturadas e também, por esta técnica, T. gondii não foi isolado em nenhuma ave.

Palavras-chave: Toxoplasma gondii, pombos, infecção experimental, bioensaio, nested-PCR.

\footnotetext{
*Corresponding author: Solange Maria Gennari

Departamento de Medicina Veterinária Preventiva e Saúde Animal,

Faculdade de Medicina Veterinária e Zootecnia,

Universidade de São Paulo - USP, Cidade Universitária, Av. Prof. Orlando

Marques de Paiva, 87, CEP 05508-270, São Paulo - SP, Brazil;

e-mail: sgennari@usp.br
} 


\section{Introduction}

Toxoplasmosis is a zoonosis of worldwide distribution caused by Toxoplasma gondii, an obligate intracellular coccidian parasite that infects most warm-blooded animals including birds, humans, domestic and wild animals (DUBEY; BEATTIE, 1988).

Routine diagnosis of $T$. gondii infection is commonly performed by serological tests for detection of specific antibodies. There are several tests available, and in veterinary medicine, the indirect fluorescent antibody test (IFAT) and modified agglutination test (MAT) are widely used. However, in chickens, T. gondii has already been isolated in serologically negative birds (DUBEY et al., 2002, 2003a, b, 2005a, 2007).

Pigeons (Columba livia) are widely distributed in all continents, except Antarctica (GIBBS et al., 2001), and they were introduced in Brazil in the sixteenth century as a domestic bird. These birds are very well adapted and proliferate without control in urban centers, attaining urban pest status (SÃO PAULO, 2010).

There are few studies (DUBEY, 2002; TSAI et al., 2006; WAAP et al., 2008; SALANT et al., 2009) investigating the pathogenesis, serology and epidemiology of toxoplasmosis in pigeons and its role and importance in public health. Pigeons are mostly flying-free birds and may be a reservoir in the spread of toxoplasmosis and a source of infection for predators and humans (BIANCIFIORI et al., 1986).

Toxoplasmosis seroprevalence studies conducted with pigeons from different continents have shown rates ranging from $4.0 \%$ to $5.9 \%$ (KIRKPATRICK et al., 1990; MUSHI et al., 2001; TSAI et al., 2006; WAAP et al., 2008).

There are only few studies on experimental infection in pigeons (SIMITCH et al. 1965; BIANCIFIORI et al., 1986; MINEO et al., 2009). Mineo et al. (2009) infected four pigeons with $1 \times 10^{7}$ tachyzoites (RH strain) of $T$. gondii. The pigeons had high titers of anti-T. gondii antibodies by IFAT with peaks at 10 to 15 days post-infection (dpi), followed by a marked decline, despite being detected until the end of the 45-day experimental period.

Pigeons infected with different doses of oocysts (50, 500, 1000 and 5000 oocysts per pigeon) of T. gondii (RH strain) have symptoms of toxoplasmosis and die, and only those who received the lowest dose survive (BIANCIFIORI et al., 1986).

The aim of this study was to measure levels of anti-T. gondii antibodies by two different serological techniques in pigeons experimentally infected and to determine the occurrence of antibodies in free-living pigeons in different municipalities of São Paulo. The sensitivity of the serological tests studied was verified by a bioassay in mice and molecular methods.

\section{Material and Methods}

\section{Experimental design}

This study was divided into two experiments (I and II). Sixteen free-living young pigeons, approximately 90 days old, were captured in the cities of Ibiúna and São Paulo, State of São Paulo, for experimental infection (Experiment I), and 126 free-living pigeons (72 from the city of Sorocaba, 36 from Ibiúna and 18 from São Paulo) were captured for testing of natural infection by detection of anti-T. gondii antibodies and isolation of the parasite by bioassay in mice (Experiment II).

In Experiment I sporulated oocysts of T. gondii, from VEG sample, were used for experimental infection of pigeons. A total of 12 pigeons were inoculated, via crop, with 50 T. gondii oocysts and four birds remained uninfected negative controls. The pigeons were divided into four groups (G1 - G4) of three infected and one control bird and they were tested at 15 (G1), 30 (G2), 45 (G3), and 60 (G4) dpi. At the end of the observation period of each group, the pigeons were euthanized with $0.3 \mathrm{~mL} \cdot \mathrm{kg}^{-1}$ of T- $61^{\oplus}$ (Intervet, Brazil) by intracardiac injection after chemical anesthesia with $0.015 \mathrm{~mL}$ of $2 \%$ xylazine (Kensol ${ }^{\oplus}$, Konig, Brazil) and $0.03 \mathrm{~mL}$ of $10 \%$ ketamine (Vetaset ${ }^{\oplus}$, Fort Dodge, Brazil) by intramuscular injection. Tissue samples were collected for polymerase chain reaction (PCR) analysis and bioassay in mice.

In Experiment II pigeons were captured in the nature and euthanized as previous described for Experiment I. Blood and tissue samples of all birds were collected for serology and isolation (bioassay in mice) of $T$. gondii, respectively.

\section{Serology}

In both Experiment I and II sera were tested for the presence of antibodies to $T$. gondii by MAT as previously described (DUBEY; DESMONTS, 1987). Sera were first screened at 1:5, 1:50 and 1:500 dilutions. Positive and negative controls were included in each test.

Sera from pigeons in Experiment I were also tested for the presence of anti- $T$. gondii antibodies by IFAT according to Camargo (1964) at a dilution of 1:4 using anti-bird conjugate (Goat anti-Bird IgG-h+I, FITC Conjugated, $1.0 \mathrm{mg} \cdot \mathrm{mL}^{-1}$, Bethyl Laboratories Inc., USA) at a dilution of 1:300. Positive sera were tested at two-fold serial dilutions. Known positive (obtained from previously infected pigeons) and negative control sera were analyzed in all reactions.

\section{Bioassay of pigeon tissues in mice}

After necropsy of the pigeons in Experiment I, the tissues collected (brain, heart, tongue and pectoral muscles) were analyzed by bioassay in mice according Dubey (1998). Heart, tongue and pectoral muscle samples were entirely used for processing, and brains were macerated separately. For each pigeon these two tissue homogenates were separately mixed with five volumes of acidic pepsin (2.6 g pepsin; $5.0 \mathrm{~g} \mathrm{NaCl} ; 7.0 \mathrm{~mL} \mathrm{HCl}$; and added distilled water to make $500 \mathrm{~mL}, \mathrm{pH} 1.1-1.2$ ), then the mixture was incubated in a shaking water bath for 1 hour at $37^{\circ} \mathrm{C}$, centrifuged, neutralized with sodium bicarbonate $(0.143 \mathrm{M})$ and mixed with antibiotics (penicillin, $1000 \mathrm{U} \cdot \mathrm{mL}^{-1}$ and streptomycin, $100 \mu \mathrm{g} \cdot \mathrm{mL}^{-1}$ ). One $\mathrm{mL}$ of the homogenate was inoculated subcutaneously (SC) into each mice. Due to low weight of pigeons, it was not always possible to aliquot $50 \mathrm{~g}$ of tissue as proposed in the original protocol. G1 mice (10 mice) were inoculated with a pool of all sampled organ tissues and G2 to G4 mice were inoculated with brain (5 mice) and a pool of organs (5 mice) separately. 
In the bioassay of pigeons in Experiment II, peptic digestion was not performed. Brain, liver and heart were homogenized with saline (v/v) and antibiotics (penicillin, 1000 U.mL ${ }^{-1}$ and streptomycin, $100 \mu \mathrm{g} \cdot \mathrm{mL}^{-1}$ ). For pigeons 1 to $50,51,52$ to 108 and 109 to 126 , two, four, three and five mice were inoculated per pigeon, respectively.

In Experiment I the bioassay was performed in two-month-old $\mathrm{BALB} / \mathrm{c}$ female mice from the animal facility of the Department of Pathology, Faculty of Veterinary Medicine, Universidade de São Paulo (FMVZ-USP). In Experiment II two-month-old female and male Swiss albino mice from the animal facility of Department of Preventive Veterinary Medicine and Animal Health at FMVZ-USP were used.

Before adding acidic pepsin, three aliquots of $1.5 \mathrm{~mL}$ of each tissue homogenate from pigeons in Experiment I were stored at $-70{ }^{\circ} \mathrm{C}$ until extraction of genomic DNA was performed.

The inoculated mice were tested for $T$. gondii infection as previously described (DUBEY; BEATTIE, 1988). Impression smears of lung and brain samples of dead mice were microscopically examined for $T$. gondii stages. Two months post-infection all surviving mice were euthanized with $0.3 \mathrm{~mL} \cdot \mathrm{kg}^{-1}$ of T- $61^{\odot}$ (Intervet, Brazil) by intrapulmonary injection and their brains were examined microscopically (a piece of brain was crushed between a cover slip and glass slide) for the presence of tissue cysts. Mice were considered infected when $T$. gondii organisms were found in their tissues. Aliquots of positive tissue from mice were also stored at $-70{ }^{\circ} \mathrm{C}$ for DNA extraction.

\section{DNA extraction}

DNA extraction was based on protocols described by Ausubel et al. (1999). After thawing of tissues of pigeons and mice, $500 \mu \mathrm{L}$ of each aliquot was separated. The samples were washed in Tris-EDTA (TE) buffer (10 mM Tris- $\mathrm{HCl}, \mathrm{pH} 8,0$; $1 \mathrm{mM}$ EDTA), and digested by overnight incubation at $37^{\circ} \mathrm{C}$ in lysis buffer (10 mM Tris- $\mathrm{HCl}, \mathrm{pH} 8.0 ; 100 \mathrm{mM} \mathrm{NaCl} ; 25 \mathrm{mM}$ EDTA; 1\%SDS; $400 \mu \mathrm{g} . \mathrm{mL}^{-1}$ proteinase K). DNA was extracted via phenol, phenol/chloroform and chloroform steps, and then precipitated with two volumes of $100 \%$ ethanol. Following overnight incubation at $-20{ }^{\circ} \mathrm{C}$ and centrifugation, each pellet was resuspended in $30 \mu \mathrm{L}$ of TE buffer, incubated for 10 minutes at $56{ }^{\circ} \mathrm{C}$ and stored at $-20{ }^{\circ} \mathrm{C}$ until use.

\section{PCR and nested-PCR}

DNA of $T$. gondii was detected by nested-PCR (n-PCR) based on primers that amplify a fragment of $155 \mathrm{pb}$ of $\mathrm{B} 1$ genes according to Burg et al. (1989). For PCR and n-PCR, an RH sample (SABIN, 1941) was included as positive control, and every three or four samples, ultrapure autoclaved water was included as negative control. The products generated by n-PCR were prepared in $2.0 \%$ agarose gel stained with ethidium bromide solution $\left(0.3 \mu \mathrm{g} . \mathrm{mL}^{-1}\right)$ in horizontal cube with TBE buffer (tris-borate $0.045 \mathrm{M}, 0.001 \mathrm{M}$ EDTA), $\mathrm{pH}$ 8.0, with a molecular weight marker with multiple fragments of 100 base pairs, and then subjected to electrophoresis. After electrophoresis, the gel was examined under transilumination with ultraviolet light for band visualization. Photographic documentation was performed with image analyzer AlphaImager Imaging System (Alpha Innotech Corp., San Leandro, CA, USA).

The nested-PCR of G1 samples was examined as a pool of organs (brain, heart, tongue and pectoral muscles) in triplicate. G2, G3 and G4 samples had brain and a pool of organs (heart, tongue and pectoral muscles) examined separately, with one brain sample and three samples of a pool of organs from each bird analyzed.

\section{Results}

In Experiment I, pigeon 16 in G4 (euthanized at $60 \mathrm{dpi}$ ) showed clinical signs of toxoplasmosis - weight loss, dehydration, ruffled feathers, and diarrhea - and died at $23 \mathrm{dpi}$ and $T$. gondii cysts were found in its brain. All other birds remained healthy during the observation period.

Seven $(58.3 \%)$ out of 12 inoculated pigeons tested positive for anti-T. gondii antibodies by MAT and IFAT, and there was good agreement between both techniques used in all samples. Titers ranged from 1:40 to $1: 5120$ by MAT and 1:512 to $1: 4096$ by IFAT during the experimental period. The Table 1 summarizes Experiment I results and antibody titers at the day birds were euthanized.

T. gondii was not isolated in four control pigeons, but in five (41.7\%) out of the 12 infected birds it was isolated by mice bioassay. In G1 (mice inoculated with a pool of organs and brain) only pigeon 2 was positive. In G2, G3 and G4 (mice inoculated with brain and a pool of organs separately) T. gondii was isolated in one (\#7), two (\#10 and 11) and one (\#14) pigeon, respectively. The bioassay of pigeon 7 was positive only with tissue pool samples and of pigeon 10 only with brain samples. Of all mice inoculated in the bioassay ( $\mathrm{n}=140), 32(22.8 \%)$ were positive to $T$. gondii.

By nested-PCR $58.3 \%$ (7/12) of the infected birds were positive to $T$. gondii and four control birds were negative. G1 pigeons that had their tissue samples tested as a pool had two positive results by nested-PCR. Among those animals tested by nested-PCR using brain samples and from a pool of organs separately (G2, G3 and $\mathrm{G} 4$ ), only pigeon 10 showed inconsistent results, with positive results obtained only with brain samples.

All samples positive in mice bioassay were also positive by nested-PCR, except in pigeon $16(\mathrm{G} 4)$ that were negative in the bioassay and positive by nested-PCR.

Regarding Experiment II, none of 126 free-living pigeons was positive for antibodies anti-T. gondii (MAT < 1:5). A total of 126 bioassays were conducted with 365 mice inoculated with biological material of these birds. During the 60-day observation, $22(6 \%)$ mice died and none of them had any form of $T$. gondii. All mice were seronegative (MAT < 1:25) when examined at the end of the bioassay and T. gondii cysts were not found in brain samples of these animals.

\section{Discussion}

The pigeons studied were only considered infected by $T$. gondii when a positive result was obtained with at least two different techniques (serological, biological or molecular). 
Table 1. Comparison of different techniques (MAT, IFAT, bioassay in mice and nested-PCR) for diagnosis of experimental Toxoplasma gondii infection in pigeons.

\begin{tabular}{|c|c|c|c|c|c|c|c|}
\hline \multirow[t]{2}{*}{ Group } & \multirow{2}{*}{$\begin{array}{c}\text { Day of } \\
\text { euthanasia } \\
\text { (dpi) }\end{array}$} & \multirow{2}{*}{$\begin{array}{c}\text { Pigeon } \\
\text { no. }\end{array}$} & \multicolumn{2}{|c|}{ Antibody titer* } & \multirow{2}{*}{$\begin{array}{l}\text { Bioassay } \\
\text { in mice }\end{array}$} & \multicolumn{2}{|c|}{ Nested-PCR } \\
\hline & & & MAT & IFAT & & Brain & TH \\
\hline \multirow[t]{4}{*}{$\mathrm{G} 1^{£}$} & 15 & $1^{\S}$ & $<5$ & $<4$ & $\mathrm{~N}$ & - & $\mathrm{N}$ \\
\hline & & 2 & 160 & 2048 & $\mathrm{P}$ & - & $\mathrm{P}$ \\
\hline & & 3 & $<5$ & $<4$ & $\mathrm{~N}$ & - & $\mathrm{N}$ \\
\hline & & 4 & 1280 & 2048 & $\mathrm{~N}$ & - & $\mathrm{P}$ \\
\hline \multirow{2}{*}{ G2 } & & 7 & 1280 & 4096 & $\mathrm{P}$ & $\mathrm{P}$ & $\mathrm{P}$ \\
\hline & & 8 & $<5$ & $<4$ & $\mathrm{~N}$ & $\mathrm{~N}$ & $\mathrm{~N}$ \\
\hline \multirow[t]{3}{*}{ G3 } & 45 & $9^{\S}$ & $<5$ & $<4$ & $\mathrm{~N}$ & $\mathrm{~N}$ & $\mathrm{~N}$ \\
\hline & & 10 & 640 & 4096 & $\mathrm{P}$ & $\mathrm{P}$ & $\mathrm{N}$ \\
\hline & & 11 & 1280 & 2048 & $\mathrm{P}$ & $\mathrm{P}$ & $\mathrm{P}$ \\
\hline \multirow{2}{*}{ G4 } & & 15 & $<5$ & $<4$ & $\mathrm{~N}$ & $\mathrm{~N}$ & $\mathrm{~N}$ \\
\hline & & $16^{\dagger}$ & 2560 & 2048 & $\mathrm{~N}$ & $\mathrm{P}$ & $\mathrm{P}$ \\
\hline
\end{tabular}

$\mathrm{dpi}=$ days post-infection; ${ }^{\circledR}$ Negative control; ${ }^{\dagger}$ Titer at $21 \mathrm{dpi}$; $\mathrm{N}=$ negative; $\mathrm{P}=$ positive; $\mathrm{TH}=$ Tissue homogenate; $£=$ pool of brain and other organ tissues;

* = antibody titer at the day of euthanasia; MAT = Modified Agglutination Test; IFAT = Indirect Fluorescent Antibody Test

With respect to the experimental infection of pigeons (Experiment I), it was found that the use of 50 sporulated oocysts of T. gondii, via crop, resulted in seroconversion of $58.3 \%(7 / 12)$ of birds (MAT $\geq 1: 5$ and IFAT $\geq 1: 4$ ) and presence of $T$. gondii DNA by PCR in birds tissues. In a study conducted using the same dose of oocysts, Biancifiori et al. (1986) reported infection in $100 \%$ of birds; however only five pigeons were used in the experiment and a different $T$. gondii strain was used to infect them.

Serum samples were collected weekly after inoculation and anti-T. gondii antibodies were detected from the first day of collection on until $7 \mathrm{dpi}$. Mineo et al. (2009) found by IFAT, using anti-chicken conjugate, high titers at day 5 pi and a pronounced decrease in the titers from the second week on. These high titers are probably due to infection using tachyzoites intraperitoneally or a different conjugate used in the IFAT. However, the pattern of antibodies observed in this study contrasts with that found by Mineo et al. (2009), with high antibody titers until the end of the observation period.

All sera of pigeons that were positive by MAT were also positive by IFAT, indicating that both techniques can be used as a reliable diagnostic method for the detection of anti- $T$. gondii antibodies in pigeons. Also, the anti-bird conjugate used in IFAT in the present study was effective for the diagnosis in pigeons. As indicated by the manufacturer, the anti-bird conjugate (Bird Goat anti-IgG + I, FITC Conjugated, Bethyl Laboratories, Inc., USA) can react with sera of pigeon, duck, sparrow and chicken. Dubey et al. (1993a, b, 1994a, b, 1995) and Sedlák et al. (2000) also concluded that MAT and IFAT are effective methods for diagnosis of anti- $T$. gondii antibodies in gallinaceous birds.

On the day animals in all groups were euthanized, positive pigeons showed high antibody titers (MAT $\geq 1: 160$; IFAT $\geq 1: 2048$ ).
These results are consistent with Mineo et al. (2009) and Biancifiori et al. (1986) studies reporting high titers in the first weeks post-infection. However, little is known about the decline in antibody levels in these birds. Mineo et al. (2009) observed that anti-T. gondii antibodies had peaks between 10-15 dpi, followed by a sharp decline, despite being detected until the end of the 45-day experiment when birds were euthanized.

Nested-PCR was sensitive (58.3\%) in detecting T. gondii DNA samples of brain and a pool of organs of infected pigeons. Pigeon 10 was the only bird in the experiment with inconsistent results between brain and organ samples, indicating there are probably no major variations in the site of cyst formation in these birds.

Bioassay is a highly sensitive test (DUBEY et al., 2005a, b, c) for detection of T. gondii from animal tissues. However, the bioassay of a single pigeon who died was negative. Dubey et al. (2005a) described that a successful isolation is dependent on the number of mice inoculated, amount of tissue used and parasite concentration in tissue samples, which are difficult to control in bioassays of pigeons as a small amount of tissue is available for infection.

In Experiment I T. gondii was isolated from tissues of five (41.7\%) out of 12 birds infected with sporulated oocysts. In the group euthanized at $15 \mathrm{dpi}$, pigeon 4 was not positive to mice bioassay, but infection was confirmed by nested-PCR and serology. All seropositive mice survived until the end of the experiment and T. gondii cysts were found in brain samples but these mice had low development, bristling and dehydration.

In Experiment II all free-living birds were tested only by MAT because it is a fast test that does not require the use of conjugates and its results showed full agreement with those of IFAT in Experiment I. All 126 birds were negative for anti-T. gondii 
antibodies. In similar studies with free-living pigeons conducted in the United States (KIRKPATRICK et al., 1990), China (TSAI et al., 2006), Portugal (WAAP et al., 2008) and Israel (SALANT et al., 2009), infection rate was 4.0 to $5.9 \%$, which is lower than seen in other gallinaceous birds, ranging from 39\% to $66 \%$ (DUBEY et al., 2002, 2003b, 2006, 2007; SILVA et al., 2003; OLIVEIRA et al., 2009).

Dubey et al. (2002, 2003a, b, 2005a, 2007), while studying free-range chickens, isolated $T$. gondii by bioassay even when tissues of negative MAT chickens were used. It is noteworthy that in these studies bioassays of negative birds were performed in cats rather than mice, but Silva et al. (2003) obtained 23.5\% (4/17) isolates of $T$. gondii using tissues of MAT seronegative chicken by bioassay in mice.

Gondim et al. (2010) using free-living sparrows (Passer domesticus) detected DNA of T. gondii in seronegative birds, confirming the importance of other diagnostic techniques to complement serological examination of birds infected with $T$. gondii. Based on these observations, in the present study all birds were tested by bioassay in mice but with no isolation of $T$. gondii.

Carnivorism with ingestion of $T$. gondii tissue cysts by cats is the most effective way of infection in the definitive host (DUBEY, 2006), and it is also known that felids are generally excellent predators, thus contributing to maintenance and success of T. gondii in the environment. Birds can be considered important reservoirs of $T$. gondii as they are often hunted by felids. Pigeons have the capacity to adapt very well to urban environments, they proliferate out of control as they are not selective about food, eating food waste that may be contaminated with $T$. gondii. In addition, as they fly long distances and can feed on the ground, they can be potential hosts of this coccidian. However, the importance of pigeons in the epidemiology of T. gondii transmission in the present study was not confirmed.

\section{Acknowledgements}

We thank the National Council for Scientific and Technological Development (CNPq) for granting a fellowship to F. S. L. Godoi and a Research Productivity fellowship to S. M. Gennari.

\section{References}

AUSUBEL, F. M. et al. (Eds.). Short protocols in molecular biology. $4^{\text {th }}$ ed. New York: Wiley, 1999.

BIANCIFIORI, F. et al. Avian toxoplasmosis: experimental infection of chicken and pigeon. Comparative Immunology, Microbiology and Infectious Diseases, v. 9, n. 4, p. 337-346, 1986.

BURG, J. L. et al. Direct and sensitive detection of a pathogenic protozoan, Toxoplasma gondii by polymerase chain reaction. Journal of Clinical Microbiology, v. 27, n. 8, p. 1787-1792, 1989.

CAMARGO, M. E. Improved technique of indirect imunofluorescence for serological diagnosis of toxoplasmosis. Revista do Instituto de Medicina Tropical de Sáo Paulo, v. 6, n. 3, p. 117-118, 1964.
DUBEY, J. P. Refinement of pepsin digestion method for isolation of Toxoplasma gondii from infected tissues. Veterinary Parasitology, v. 74, n. 1, p. 75-77, 1998.

DUBEY, J. P. A review of toxoplamosis in wild birds. Veterinary Parasitology, v. 106, n. 2, p. 121-153, 2002.

DUBEY, J. P. Comparative infectivity of oocysts and bradyzoites of Toxoplasma gondii for intermediate (mice) and definitive (cats) hosts. Veterinary Parasitology, v.140, n. 1-2, p. 69-75, 2006.

DUBEY, J. P.; BEATTIE, C. P. Toxoplasmosis of animals and man. Toxoplasmosis in birds. Boca Raton, Florida: CRC Press, 1988. p. $151-153$.

DUBEY, J. P.; DESMONTS, G. Serological responses of equids fed Toxoplasma gondii oocysts. Equine Veterinary Journal, v. 19, n. 4, p. 337-339, 1987.

DUBEY, J. P. et al. Experimental toxoplasmosis in turkeys. Journal of Parasitology, v. 79, n. 6, p. 949-952, 1993 a.

DUBEY, J. P. et al. Experimental toxoplasmosis in Bobwhite quail (Colinus virginianus). Journal of Parasitology, v. 79, n. 6, p. 935-939, 1993b.

DUBEY, J. P. et al. Experimental toxoplasmosis in Japanese quail. Journal of Veterinary Diagnostic Investigation, v. 6, n. 2, p. 216-221, $1994 a$.

DUBEY, J. P. et al. Experimental toxoplasmosis in pheasants (Phasianus colchicus). Journal of Wildlife Diseases, v. 30, n. 1, p. 40-45, $1994 \mathrm{~b}$.

DUBEY, J. P. et al. Experimental toxoplasmosis in chukar partridges (Alectoris graeca). Avian Pathology, v. 24, n. 1, p. 95-107, 1995.

DUBEY, J. P. et al. Biological and genetic characterisation of Toxoplasma gondii isolates from chickens (Gallus domesticus) from Sáo Paulo, Brazil: unexpected findings. International Journal for Parasitology, v. 32, n. 1, p. 99-105, 2002.

DUBEY, J. P. et al. Toxoplasma gondii isolates of free-ranging chickens from Rio de Janeiro, Brazil: mouse mortality, genotype, and oocyst shedding by cats. Journal of Parasitology, v. 89, n. 4, p. 851-853, 2003a.

DUBEY, J. P. et al. Characterization of Toxoplasma gondii isolates from free range chickens from Paraná, Brazil. Veterinary Parasitology, v. 117, n. 3, p. 229-234, 2003b.

DUBEY, J. P. et al. Characterization of Toxoplasma gondii isolates in free-range chickens from Amazon, Brazil. Journal of Parasitology, v. 92, n. 1, p. 36-40, 2006.

DUBEY, J. P. et al. Biologic and genetic comparison of Toxoplasma gondii isolates in free-range chickens from the northern Pará state and the southern state Rio Grande do Sul, Brazil revealed highly diverse and distinct parasite populations. Veterinary Parasitology, v. 143, n. 2, p. 182-188, 2007.

DUBEY, J. P. et al. Genetic and biologic characteristics of Toxoplasma gondii isolates in free-range chickens from Colombia, South America. Veterinary Parasitology, v. 134, n. 1-2, p. 67-72, 2005 a.

DUBEY, J. P. et al. Toxoplasma gondii infections in chickens from Venezuela: isolation, tissue distribution, and molecular characterization. Journal of Parasitology, v. 91, n. 6, p. 1332-1334, 2005b.

DUBEY, J. P.; MARCET, P. L.; LEHMANN, T. Characterization of Toxoplasma gondii isolates in free-range chickens from Argentina. Journal of Parasitology, v. 91, n. 6, p. 1335-1339, 2005c. 
GIBBS, D.; BARNES, E.; COX, J. Pigeons and doves: a guide to pigeons and doves of the world. New Haven, Connecticut: Yale University Press, 2001.

GONDIM, L. S. Q. et al. Toxoplasma gondii and Neospora caninum in sparrows (Passer domesticus) in the Northeast of Brazil. Veterinary Parasitology, v. 168, n. 1-2, p. 121-124, 2010.

KIRKPATRICK, C. E.; COLVIN, B. A.; DUBEY, J. P. Toxoplasma gondii antibodies in common barn-owls (Tyto alba) and pigeons (Columba livia) in New Jersey. Veterinary Parasitology, v. 36, n. 1-2, p. $177-180,1990$.

MINEO, T. W. P. et al. Pigeons (Columba livia) are a suitable experimental model for Neospora caninum infection in birds. Veterinary Parasitology, v. 159, n. 2, p. 149-153, 2009.

MUSHI, E. Z. et al. Seroprevalence of Toxoplasma gondii and Chlamydia psittaci in domestic pigeons (Columba livia domestica) at Sebele, Gaborone, Botswana. Onderstepoort Journal of Veterinary Research, v. 68 , n. 2, p. 159-161, 2001.

OLIVEIRA, L. N. et al. Toxoplasma gondii isolates from free-range chickens from the northeast region of Brazil. Journal of Parasitology, v. 95 , n. 1, p. 235-237, 2009.

SABIN, A. B. Toxoplasmic encephalitis in children. Journal of the American Medical Association, v. 116, n. 9, p. 801-807, 1941.

SALANT, H.; LANDAU, D. Y.; BANETH, G. A cross-sectorial survey of Toxoplasma gondii antibodies in Israeli pigeons. Veterinary Parasitology, v. 165 , n. $1-2$, p. $145-149,2009$.
SÃO PAULO (Município). Secretaria Municipal da Saúde. Centro de Controle de Zoonoses. Divisão Técnica de Controle de Roedores e Vetores. Setor de Culicídeos. Manejo de pombos urbanos. Organização de Eunice Santos Martini Padori. São Paulo: PMSP/SMS/CCZ, [200-?]. Disponível em: <http://ww2.prefeitura.sp.gov.br//arquivos/secretarias/ saude/vigilancia_saude/ccz/ 0028/PombosUrbanos.pdf>. Acesso em: 4 nov. 2010

SEDLÁK, K. et al. High susceptibility of partridges (Perdix perdix) to toxoplasmosis compared with other gallinaceous birds. Avian Pathology, v. 29 , n. 6, p. 563-569, 2000.

SILVA, D. S. et al. Prevalence of Toxoplasma gondii in chickens from an area in Southern Brazil highly endemic to humans. Journal of Parasitology, v. 89, n. 2, p. 394-396, 2003.

SIMITCH, T. et al. Infection expérimentale du pigeon per os, avec la forme végétative et la forme kystique de Toxoplasma gondii. Bulletin de l'Académie Vétérinarie de France, v. 38, n. 8, p. 333-336, 1965.

TSAI, Y. J. et al. Prevalence of antibodies to Toxoplasma gondii in pigeons (Columba livia) in Taiwan. Journal of Parasitology, v. 92, n. 4, p. 871, 2006.

WAAP, H. et al. Epidemiological and genetic characterization of Toxoplasma gondii in urban pigeons from the area of Lisbon (Portugal). Veterinary Parasitology, v. 157, n. 3-4, p. 306-309, 2008. 